\title{
Adsorption of Phosphate from Aqueous Solution onto Iron-coated Waste Mussel Shell: Physicochemical Characteristics, Kinetic, and Isotherm Studies
}

\author{
Nur Atikah Abdul Salim 1, 2,* (D), Mohamad Ali Fulazzaky ${ }^{3}$, Mohd Hafiz Puteh 1,2,*, \\ Mohd Hairul Khamidun ${ }^{4}$, Abdull Rahim Mohd Yusoff ${ }^{5}$, Noorul Hudai Abdullah ${ }^{6}$, Noraziah Ahmad ${ }^{1}$, \\ Zainab Mat Lazim ${ }^{1}$, Maria Nuid ${ }^{1}$
}

1 School of Civil Engineering, Faculty of Engineering, Universiti Teknologi Malaysia, 81310 UTM Johor, Malaysia

2 Centre for Environmental Sustainability and Water Security, Research Institute for Sustainable Environment, Universiti Teknologi Malaysia, 81310 UTM Johor, Malaysia

3 School of Postgraduate Studies, Djuanda University, 16720 Bogor, Indonesia

4 Faculty of Civil and Environmental Engineering, Universiti Tun Hussein Onn Malaysia, 86400 UTHM, Johor, Malaysia

5 Faculty of Science, Universiti Teknologi Malaysia, 81310 UTM Johor, Malaysia

6 Centre For Diploma Studies, Faculty of Civil Engineering, Universiti Tun Hussein Onn Malaysia, 84600 UTHM, Johor, Malaysia

* Correspondence: atikahsalim@gmail.com (N.A.A.S); natikah57@live.utm.my (N.A.A.S); mhafizputeh@utm.my (M.H.P);

Received: 20.12.2020; Revised: 17.01.2021; Accepted: 21.01.2021; Published: 31.01.2021

\begin{abstract}
High amounts of phosphate $\left(\mathrm{PO}_{4}{ }^{3-}\right)$ discharged in receiving water can lead to eutrophication, which endangers life below water and human health. This study elucidates the removal of $\mathrm{PO}_{4}{ }^{3-}$ from synthetic solution by iron-coated waste mussel shell (ICWMS). The $\mathrm{PO}_{4}{ }^{3-}$ adsorption by ICWMS was determined at different process parameters, such as initial $\mathrm{PO}_{4}{ }^{3-}$ concentration $\left(7 \mathrm{mg} \mathrm{L}^{-1}\right)$, solution volume $(0.2 \mathrm{~L})$, adsorbent dosage $(4,8,12,16$, and $20 \mathrm{~g})$, and contact time. The highest efficiency of $\mathrm{PO}_{4}{ }^{3-}$ removal can reach $96.9 \%$ with an adsorption capacity of $0.30 \mathrm{mg} \mathrm{g}^{-1}$ could be obtained after a contact time of $48 \mathrm{~h}$ for the use of $20 \mathrm{~g}$ of ICWMS. Batch experimental data can be well described by the pseudo-second-order kinetic model $\left(R^{2}=0.999\right)$ and Freundlich isotherm model $\left(R^{2}=0.996\right)$, suggesting that chemisorption and multilayer adsorption occurred. The efficiency of $\mathrm{PO}_{4}{ }^{3-}$ removal from aqueous solution by ICWMS was verified to contribute to applying a new low-cost adsorbent obtained from waste mussel shell in the field of wastewater treatment.
\end{abstract}

Keywords: adsorption; eutrophication; iron-coated waste mussel shell; isotherm model; kinetic model; phosphate.

\footnotetext{
(c) 2021 by the authors. This article is an open-access article distributed under the terms and conditions of the Creative Commons Attribution (CC BY) license (https://creativecommons.org/licenses/by/4.0/).
}

\section{Introduction}

Phosphorus $(\mathrm{P})$ is a key nutrient that stimulates the development of biological organisms and algae. However, the discharge of an excessive amount of $\mathrm{P}$ into surface water strongly accelerates eutrophication [1,2]. Over-enrichment of $\mathrm{P}$ in water bodies expedites plant growth and causing algal blooms [3]. The water body may also lose its important functions and cause negative effects on the environment and human health [4]. The principal forms of $\mathrm{P}$ in water are orthophosphate, polyphosphate, and organically bound phosphate. The most common $\mathrm{P}$ compound in wastewater is orthophosphate $[5,6]$. The effects of $\mathrm{P}$ to surface water release have led to legislation such as those by the United State Environmental Protection Agency 
(USEPA) and the European Union (EU). The USEPA permits the effluent limit of total phosphorus (TP) of less than $0.8 \mathrm{mg} \mathrm{L}^{-1}$. Meanwhile, the EU allows the discharge limit of 2 $\operatorname{mg~P~L~}{ }^{-1}$ for $10,000-100,000$ population equivalents [7].

The excessive amounts of $\mathrm{P}$ can be treated with various methods such as adsorption technique, biological process, and chemical process. The biological process to treat wastewater can be highly variable due to operational difficulties [8,9], while the chemical treatment entails high chemical costs [10]. From all these removal methods, adsorption is the potential technologies that could be employed to remove $\mathrm{P}$ from water given its simple reaction and low cost of the materials $[11,12]$. Several studies have shown that some waste materials such as sand and eggshell coated with iron could be favorable and inexpensive adsorbent for $\mathrm{PO}_{4}{ }^{3-}$ removal [13-15]. Mussel shells are waste products from food processing areas and are usually dumped in foreshores. It can also be used as a low-cost adsorbent material to eliminate $\mathrm{PO}_{4}{ }^{3-}$ from water [16].

This study aimed to delve into the feasibility of utilizing ICWMS for $\mathrm{PO}_{4}{ }^{3-}$ removal from synthetic solution. The influence of the initial $\mathrm{PO}_{4}{ }^{3-}$ concentration $(\mathrm{Ci})$, adsorbent dosage $(m)$, and contact time $(t)$ on the $\mathrm{PO}_{4}{ }^{3-}$ removal was scrutinized. Freundlich and Langmuir isotherm models were employed to understand the adsorption mechanism.

\subsection{Adsorption kinetics and isotherms}

\subsubsection{Kinetics adsorption models.}

The adsorption kinetic is of interest for many aspects of surface chemistry to elucidate the mechanisms and potential rate-controlling step of the adsorption process $[17,18]$. The mechanism of the adsorption process was described by using two different types of adsorption kinetic models, namely pseudo-first-order (PFO) and pseudo-second-order (PSO) (Table 1). PFO equation can be expressed as given in Eq. (1) [19]-[21]:

$$
\ln \left(q_{e}-q_{t}\right)=\ln \left(q_{e}\right)-k_{1} t
$$

PSO equation can be expressed as [22]:

$$
\frac{t}{q_{t}}=\frac{1}{k_{2} q_{e}^{2}}+\frac{t}{q_{e}}
$$

\begin{tabular}{|c|c|c|c|}
\hline Models & Linear form & Plot & Parameters \\
\hline$\underline{\underline{\text { Kinetic }}}$ & & & \\
\hline PFO & $\ln \left(q_{e}-q_{t}\right)=\ln \left(q_{e}\right)-k_{1} t_{i}$ & $\ln \left(q_{\mathrm{e}}-q_{\mathrm{t}}\right)$ vs. $t_{\mathrm{i}}$ & $\begin{array}{l}q_{\mathrm{e}} \\
k_{1}\end{array}$ \\
\hline PSO & $\frac{t_{i}}{q_{t}}=\frac{1}{k_{2} q_{e}^{2}}+\frac{t_{i}}{q_{e}}$ & $\frac{t_{i}}{q_{t}}$ vs. $t_{i}$ & $\begin{array}{l}q_{\mathrm{e}} \\
k_{2}\end{array}$ \\
\hline Isotherm & & & \\
\hline Freundlich & $\ln q_{e}=\ln K_{F}+\frac{1}{n} \ln C_{e}$ & $\ln q_{\mathrm{e}} v s . \ln C_{\mathrm{e}}$ & $\begin{array}{l}K_{\mathrm{F}} \\
n\end{array}$ \\
\hline Langmuir & $\frac{1}{q_{e}}=\frac{1}{K_{L} q_{\max } C_{e}}+\frac{1}{q_{\max }}$ & $\frac{1}{q_{e}} v s \cdot \frac{1}{C_{e}}$ & $\begin{array}{l}q_{\max } \\
K_{\mathrm{L}} \\
\end{array}$ \\
\hline $\begin{array}{l}\text { Nomenclature } \\
k_{1} \\
k_{2} \\
K_{\mathrm{F}} \\
K_{\mathrm{L}} \\
n \\
C_{\mathrm{e}} \\
q_{\mathrm{e}} \\
q_{\mathrm{t}} \\
q_{\max } \\
t_{\mathrm{i}}\end{array}$ & \multicolumn{3}{|l|}{$\begin{array}{l}\text { PFO constant }\left(\mathrm{min}^{-1}\right) \\
\text { PFO constant }\left(\mathrm{g} \mathrm{mg}^{-1} \mathrm{~min}^{-1}\right) \\
\text { Freundlich constant }\left(\mathrm{mg} \mathrm{g}^{-1}\right) \\
\text { adsorption energy coefficient }\left(\mathrm{L} \mathrm{mg}^{-1}\right) \\
\text { heterogeneity factor (dimensionless) } \\
\text { concentration of the adsorbate at equilibrium }\left(\mathrm{mg} \mathrm{L}^{-1}\right) \\
\text { adsorption capacity at equilibrium }\left(\mathrm{mg} \mathrm{g}^{-1}\right) \\
\text { adsorption capacity at time } t\left(\mathrm{mg} \mathrm{g}^{-1}\right) \\
\text { maximum adsorption capacity }\left(\mathrm{mg} \mathrm{g}^{-1}\right) \\
\text { adsorption time (min) }\end{array}$} \\
\hline
\end{tabular}

Table 1. List of kinetic and isotherm adsorption models. 


\subsection{Isotherm adsorption models.}

The Freundlich and Langmuir equations are the equations commonly used to describe adsorption isotherms. The Freundlich model describes that the adsorbates' heterogeneous surface is formed on the surface of adsorbent with multilayer sorption of different energies of adsorption [23]. The Langmuir model assumes that the adsorbent is being saturated when the monolayer adsorbate coverage of the adsorbent is attached with a homogenous surface without interactions between the adsorbed molecules [24]. The linear form of the Freundlich isotherm can be written as [25]:

$$
\ln q_{e}=\ln K_{F}+\frac{1}{n} \ln C_{e}
$$

The Freundlich isotherm suggests that a plot $\ln q_{\mathrm{e}}$ against $\ln C_{\mathrm{e}}$ of the Eq. (3) should give a straight-line intercept at $K_{\mathrm{F}}$ with $1 / n$ as the slope (Table 1 ). The adsorption coefficient $K_{\mathrm{F}}$ may indicate the affinity of the adsorbate-adsorbent. The exponent $n$ is related to the energetic heterogeneity of the adsorbent surface and determines either the favorable or unfavorable curve [12].

The linear form of the Langmuir isotherm can be expressed as [26]:

$$
\frac{1}{q_{e}}=\frac{1}{K_{L} q_{\max } C_{e}}+\frac{1}{q_{\max }}
$$

The value of $K_{\mathrm{L}}$ and $q_{\text {max }}$ represents the Langmuir bonding term related to interaction energies and the maximum adsorption capacity, respectively.

\section{Materials and Methods}

\subsection{Adsorbents.}

Waste mussel shell (WMS) was used as an adsorbent in this study. The WMS was collected from riverbank areas in Pasir Gudang, Johor, Malaysia. The sample was washed several times with tap water, and the cleaned sample was naturally dried in the open air for 48 $\mathrm{h}$. The sample was crushed and finally sieved to particle sizes with a range of 0.60-1.18 mm.

For the preparation of ICWMS, a solution of $0.5 \mathrm{M}$ Fe (III) was prepared by dissolving $\mathrm{Fe}\left(\mathrm{NO}_{3}\right)_{3} .9 \mathrm{H}_{2} \mathrm{O}$ in deionized water (DW). A $5.0 \mathrm{~N} \mathrm{NaOH}$ base solution was added using dropper into $0.5 \mathrm{M} 100 \mathrm{~mL}$ of $\mathrm{Fe}$ (III) solution until it reached a $\mathrm{pH}$ of $9.5 \pm 0.1$. About $200 \mathrm{~g}$ sample of WMS was added to $100 \mathrm{~mL}$ of $0.5 \mathrm{M} \mathrm{Fe}$ (III). The mixture was agitated on a shaker at room temperature with a constant speed of $160 \mathrm{rpm}$ for $24 \mathrm{~h}$. Then, the ICWMS was washed with DW until the run-off reached a $\mathrm{pH}$ of 7 and dried at $100^{\circ} \mathrm{C}$ for $8 \mathrm{~h}$ [27]. The dried ICWMS was used as an adsorbent for removing $\mathrm{PO}_{4}{ }^{3-}$ from the synthetic solution.

\subsection{Synthetic solutions.}

Synthetic solutions (i.e., $100 \mathrm{mg} \mathrm{P} \mathrm{L}^{-1}$ ) was prepared by dissolving anhydrous potassium dihydrogen phosphate $\left(\mathrm{KH}_{2} \mathrm{PO}_{4}\right)$ (analytic grade) into $1 \mathrm{~L}$ of $\mathrm{DW}$. The synthetic solution was diluted with DW to get the desired concentration, and the solution was set up at pH 7.

\subsection{Analytical methods.}

The measurements of $\mathrm{PO}_{4}{ }^{3-}$ were determined using an amino acid method (UV-Vis Spectrophotometer, HACH DR 6000, United States) [28]. The portable $\mathrm{pH}$ meter (Jenway Model $350 \mathrm{pH}$ meter) was used to measure $\mathrm{pH}$. A scanning electron microscope (SEM) (Model 
TM3000, Hitachi, Japan) was used to characterize the surface morphology of the unmodified adsorbents. Types of mineral phases in the ICWMS were identified using a Bruker D8 advance high-resolution X-Ray Diffractometer (XRD). The chemical composition (in \%) of ICWMS was analyzed using Energy Dispersive X-Ray Fluorescence (EDXRF) Spectrometer (Rigaku, Japan). The functional groups of the ICWMS were investigated using Fourier Transform Infrared (FTIR) Spectroscopy (IRTracer-100, Shimadzu, Japan). The measurement of the specific surface area of ICWMS was performed by the multiple-point method according to the Brunauer, Emmett, and Teller (BET) theory, using a surfer analyzer (Surface Analyzer, Thermo Scientific Technologies, Italy).

\subsection{Batch experiments.}

In batch experiments, the equilibrium adsorption kinetics were investigated by adding 4, 12, and $20 \mathrm{~g}$ of the ICWMS. The equilibrium adsorption isotherm experiments were determined by adding 4, 8, 12, 16, and $20 \mathrm{~g}$ of the ICWMS into different Erlenmeyer flask containing $0.2 \mathrm{~L}$ of $7 \mathrm{mg} \mathrm{L}^{-1} \mathrm{PO}_{4}{ }^{3-}$ solution. Each sample was shaken at $160 \mathrm{rpm}$. Afterward, the concentrations of $\mathrm{PO}_{4}{ }^{3-}$ in each flask were determined at certain time intervals until reaching the equilibrium stage. The sample solutions were centrifuged. The HACH DR 6000 UV-Vis Spectrophotometer was used to evaluate supernatant concentrations of $\mathrm{PO}_{4}{ }^{3-}$ present in each Erlenmeyer flask. The PFO and PSO models were applied to understand the adsorption kinetics. The adsorption isotherms of $\mathrm{PO}_{4}{ }^{3-}$ onto ICWMS were explored by using Freundlich and Langmuir isotherm models. Each batch adsorption experiment was conducted twice, and the data obtained are the average values. The adsorption capacity $(q)$ and the $E$ were calculated using Eq. (5) and Eq. (6), respectively.

$$
\begin{gathered}
q=\frac{\left(C_{i}-C_{f}\right) \times V}{m} \\
E=\frac{C_{i}-C_{f}}{C_{i}} \times 100 \%
\end{gathered}
$$

\section{Results and Discussion}

\subsection{Physicochemical characteristics of the ICWMS.}

As depicted in Table 2, the major chemical compositions of ICWMS discovered in this study are $\mathrm{CaO}(87.90 \%)$ and $\mathrm{Fe}_{2} \mathrm{O}_{3}(5.93 \%)$, while the minor compositions are $\mathrm{SrO}(0.37 \%)$, $\mathrm{MgO}(0.10 \%)$, and $\mathrm{Al}_{2} \mathrm{O}_{3}(0.06 \%)$.

Table 2. Composition of the ICWMS and WMS (wt.\%) by EDXRF.

\begin{tabular}{c|c|c|c|c|c|c|c}
$\mathbf{C a O}$ & $\mathbf{F e}_{2} \mathbf{O}_{3}$ & $\mathbf{S r O}$ & $\mathbf{M g O}$ & $\mathbf{A l}_{\mathbf{2}} \mathbf{O}_{\mathbf{3}}$ & $\mathbf{K}_{2} \mathbf{O}$ & $\mathbf{N a}_{2} \mathbf{O}$ & $\mathbf{P}_{\mathbf{2}} \mathbf{O}_{\mathbf{5}}$ \\
\hline 87.90 & 5.93 & 0.37 & 0.10 & 0.06 & ND & ND & ND \\
Remarks that ND is not detected.
\end{tabular}

The SEM micrograph images with 1500, 6000, and 10000 times are shown in Figure 1. As shown in Figs. 1a and b, the surface feature of ICWMS were relatively rough. The ICWMS surfaces were occupied by iron oxides formed during the coating process [14]. The SEM image with 10000 times magnification exhibits small pores at the surface of the ICWMS (Figure 1c). 

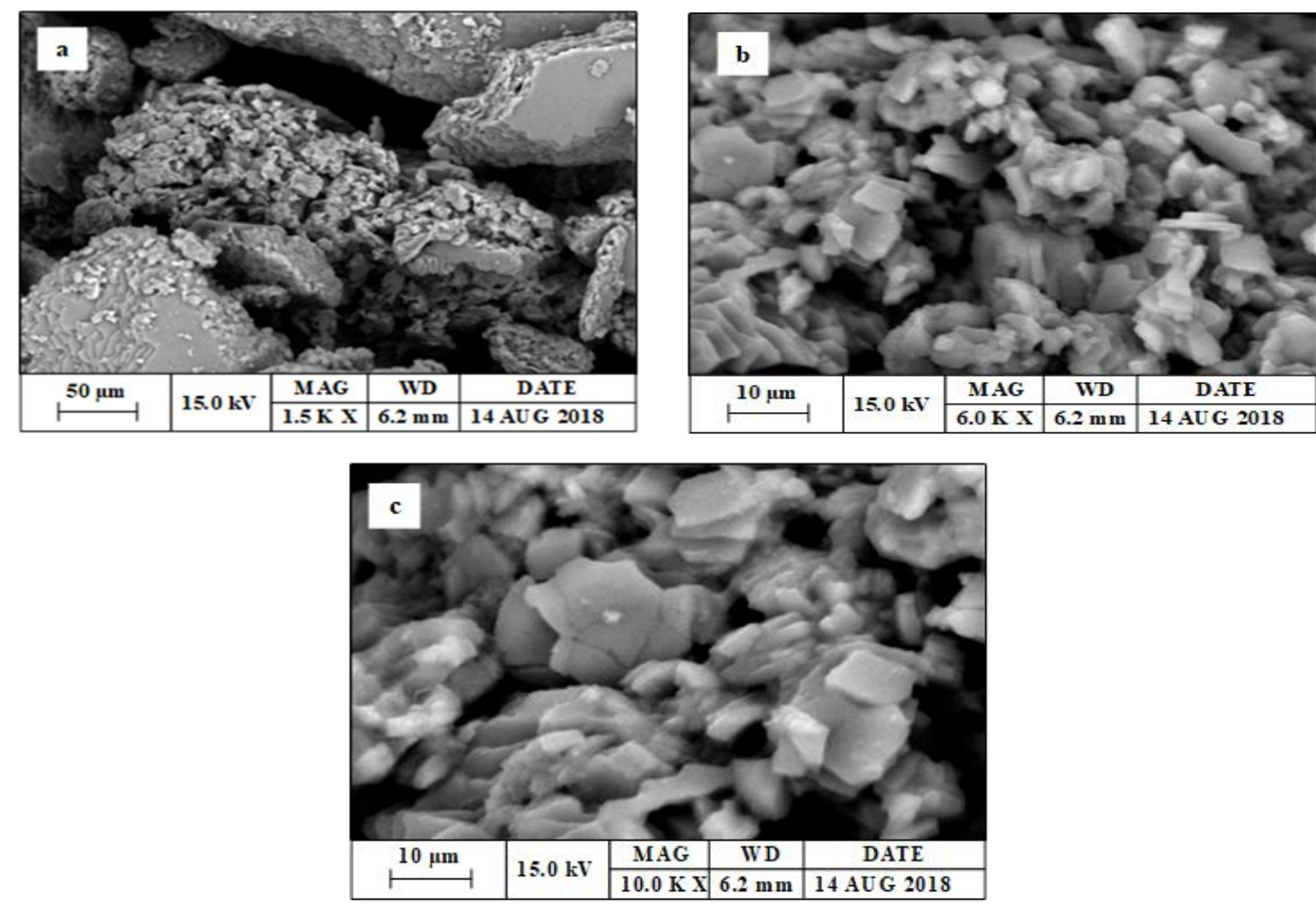

Figure 1. The SEM photomicrograph of ICWMS: (a) SEM images of $1500 \times$ (b) $6000 \times$ and (c) $10000 \times$ magnifications.

The XRD pattern (Figure 2) of the ICWMS sample indicates that calcium carbonate $\left(\mathrm{CaCO}_{3}\right)$, calcium oxide $(\mathrm{CaO})$, and iron oxide $\left(\mathrm{Fe}_{2} \mathrm{O}_{3}\right)$ are the major component of the ICWMS of Skudai. The other components listed on the XRD pattern are strontium oxide ( $\mathrm{SrO})$, magnesium oxide $(\mathrm{MgO})$, and aluminum oxide $\left(\mathrm{Al}_{2} \mathrm{O}_{3}\right)$. Several researchers have reported that $\mathrm{CaCO}_{3}$ and $\mathrm{CaO}$ have good adsorption ability for $\mathrm{PO}_{4}{ }^{3-}$ ions. The work of Torit et al. [29] affirmed that a high calcium material content could increase $\mathrm{PO}_{4}{ }^{3-}$ adsorption associated with the ability for calcium to form $\mathrm{HCO}_{3}-\mathrm{Ca}-\mathrm{HPO}_{4}$ at the carbonate sites. Nam et al. [30] proved that $\mathrm{PO}_{4}{ }^{3-}$ was effectively adsorb by a material containing a high calcium element. Besides that, iron-based materials have been reported as an effective adsorbent for removing $\mathrm{PO}_{4}{ }^{3-}$ in an aqueous solution; $\mathrm{PO}_{4}{ }^{3-}$ reacts with two singly coordinated $\mathrm{Fe}-\mathrm{OH}$ groups to form $(\mathrm{Fe}-\mathrm{O})_{2}-$ $\mathrm{PO}_{2} \mathrm{H}[10]$.

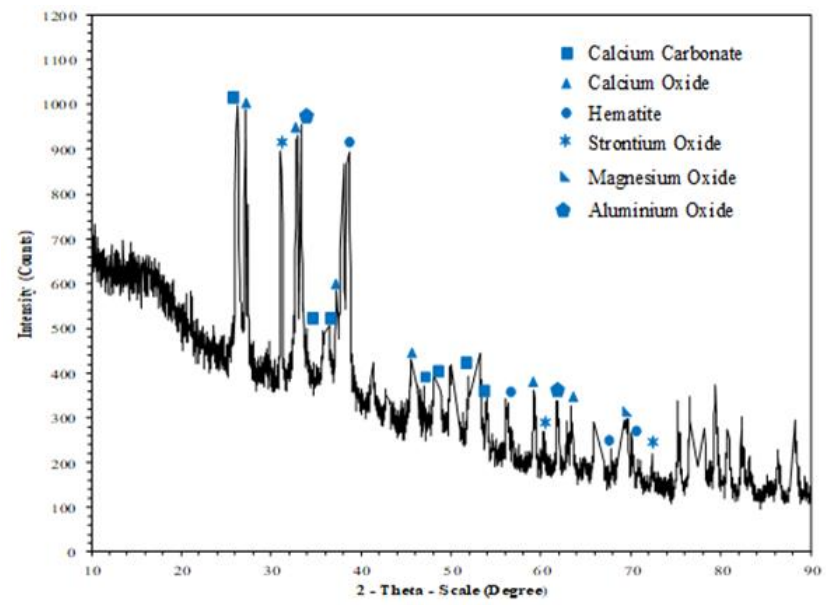

Figure 2. X-ray diffraction patterns of ICWMS. 
The FTIR spectra (see Figure 3) of natural and $\mathrm{PO}_{4}{ }^{3-}$ adsorbed ICWMS were carried out over the range from 600 to $4000 \mathrm{~cm}^{-1}$ and were compared with each other to obtain information on the modifications and surface functional groups [31]-[33]. The FTIR spectral characteristics of ICWMS before and after adsorption of $\mathrm{PO}_{4}{ }^{3-}$ ions are listed in Table 3 . The position and shape of the $\mathrm{PO}_{4}{ }^{3-}$ stretching band in the FTIR spectra of the ICWMS are influenced by the nature and position of the surface functional groups. The tetrahedral $\mathrm{PO}_{4}{ }^{3-}$ molecules are coordinated [34].

Before the adsorption of $\mathrm{PO}_{4}{ }^{3-}$, the FTIR spectral results with two bands observed at 860 and $712 \mathrm{~cm}^{-1}$ would confirm the presence of iron oxide [35,36]. After the adsorption of $\mathrm{PO}_{4}{ }^{3-}$ solute from synthetic solution onto the ICWMS, a new peak located at $1,467 \mathrm{~cm}^{-1}$ was observed and could be associated to the vibrational modes of the $\mathrm{H}_{2} \mathrm{PO}_{4}{ }^{-}$and $\mathrm{HPO}_{4}{ }^{2-}$ substituted at the $\mathrm{CO}_{3}{ }^{2-}$ on the surface of ICWMS; the inner-sphere surface complexes were formed through Lewis acid-base interactions between $\mathrm{PO}_{4}{ }^{3-}$ and $\equiv \mathrm{Ca}-\mathrm{CO}_{3}$ [37]. The peak shifted from 3,446 to $3,393 \mathrm{~cm}^{-1}$ is due to O-H stretching bands at the surface of ICWMS are affected by asymmetric stretching mode of vibration for $\mathrm{PO}_{4}{ }^{3-}$ group [38]. The band near 2,365 $\mathrm{cm}^{-1}$ was obtained for PO-H stretching [39]. The peak at $1,083 \mathrm{~cm}^{-1}$ was corresponded to the $\mathrm{PO}_{4}{ }^{3-}$ bending $[39,40]$. The influence of the $\mathrm{PO}_{4}{ }^{3-}$ molecules adsorbed onto the surface of ICWMS on Fe-O-H bending may increase a $2 \mathrm{~cm}^{-1}\left(714-712 \mathrm{~cm}^{-1}\right)$ and $\left(862-860 \mathrm{~cm}^{-1}\right)$ frequency spectrum due to ion exchange between $\mathrm{PO}_{4}{ }^{3-}$ and $\mathrm{Fe}-\mathrm{O}-\mathrm{H}$ functional group can affect the stretching because of the vibrations $[35,36]$. The peak at $1,384 \mathrm{~cm}^{-1}$ could be assigned as synthesis residue associated with $\mathrm{NO}_{3}{ }^{-}$group disappears during the adsorption process [41].

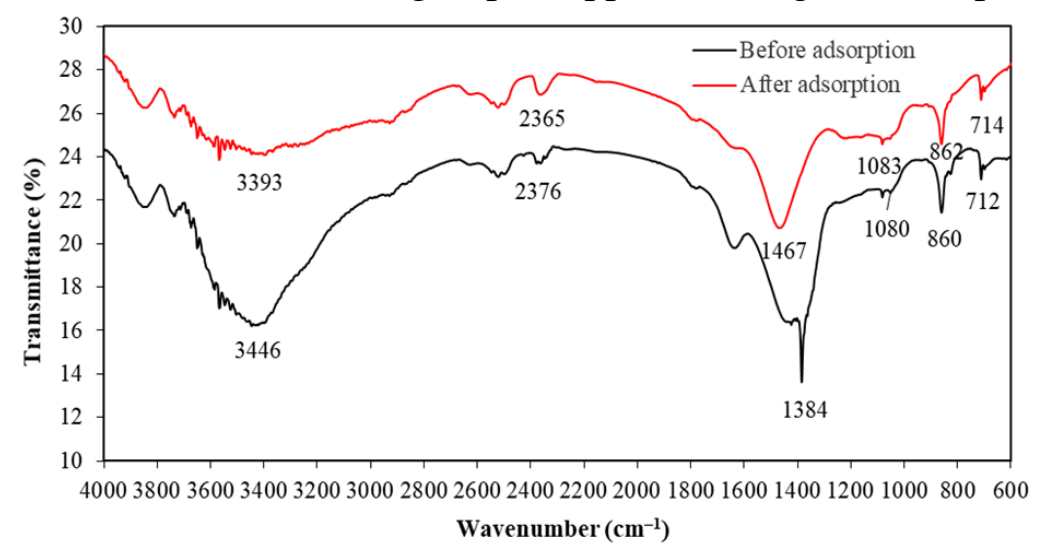

Figure 3. The FTIR spectra of ICWMS of before and after $\mathrm{PO}_{4}{ }^{3-}$ adsorption.

Table 3. FTIR spectral characteristics of ICWMS before and after adsorption of $\mathrm{PO}_{4}{ }^{3-}$ ions.

\begin{tabular}{|c|c|c|c|c|}
\hline \multicolumn{3}{|c|}{ Frequency spectrum $\left(\mathrm{cm}^{-1}\right)$} & \multirow{2}{*}{$\begin{array}{c}\text { Detection of functional } \\
\text { group }\end{array}$} & \multirow[t]{2}{*}{ Reference } \\
\hline $\begin{array}{c}\text { Before } \\
\text { adsorption }\end{array}$ & $\begin{array}{c}\text { After } \\
\text { adsorption }\end{array}$ & Differences & & \\
\hline 3446 & 3393 & -53 & $\mathrm{OH}^{-}$stretching bands & [40] \\
\hline 2376 & 2365 & -11 & $\mathrm{PO}-\mathrm{H}$ stretching & [39] \\
\hline- & 1467 & - & OH- stretching bands & [39] \\
\hline 1384 & - & - & $\mathrm{N}-\mathrm{O}$ stretching band & [41] \\
\hline 1080 & 1083 & 3 & $\mathrm{P}-\mathrm{O}$ bending & {$[39,40]$} \\
\hline 860 & 862 & 2 & $\mathrm{Fe}-\mathrm{O}-\mathrm{H}$ bending & {$[35,36]$} \\
\hline 712 & 714 & 2 & $\mathrm{Fe}-\mathrm{O}-\mathrm{H}$ bending & {$[35,36]$} \\
\hline
\end{tabular}

3.2. Variations of $\mathrm{PO}_{4}{ }^{3-}$ removal efficiency and adsorption capacity.

As shown in Figure 4, the efficiency of $\mathrm{PO}_{4}{ }^{3-}$ removal can reach 86.1, 94.8, and 96.9\% for removing $\mathrm{PO}_{4}{ }^{3-}$ after a contact time of $48 \mathrm{~h}$ with the amounts of ICWMS 4, 12, and $20 \mathrm{~g}$, respectively. $\mathrm{PO}_{4}{ }^{3-}$ removal efficiency promptly increases for the period of $1,2.5$, and $3.5 \mathrm{~h}$. It 
then slowly increases until it reaches a constant value (see Figure 4). The rapid removal of $\mathrm{PO}_{4}{ }^{3-}$ from aqueous solution by ICWMS during the first $3.5 \mathrm{~h}$ of the experimental run may be due to the availability of many free binding sites on the surface of the ICWMS [43]. According to the results of a batch experiment, the ability of ICWMS as an adsorbent can attract $\mathrm{PO}_{4}{ }^{3-}$ because the affinity between $\mathrm{Fe}_{2} \mathrm{O}_{3}$ on the surface of ICWMS and $\mathrm{PO}_{4}{ }^{3-}$ is quite strong due to the reaction of these two compounds with the presence of guest components containing hydroxyl groups $(-\mathrm{OH})$, which can form hydrogen bonds, the complex of iron-hydroxyphosphate can be significantly stabilized in the forms of amorphous or crystalline [44].

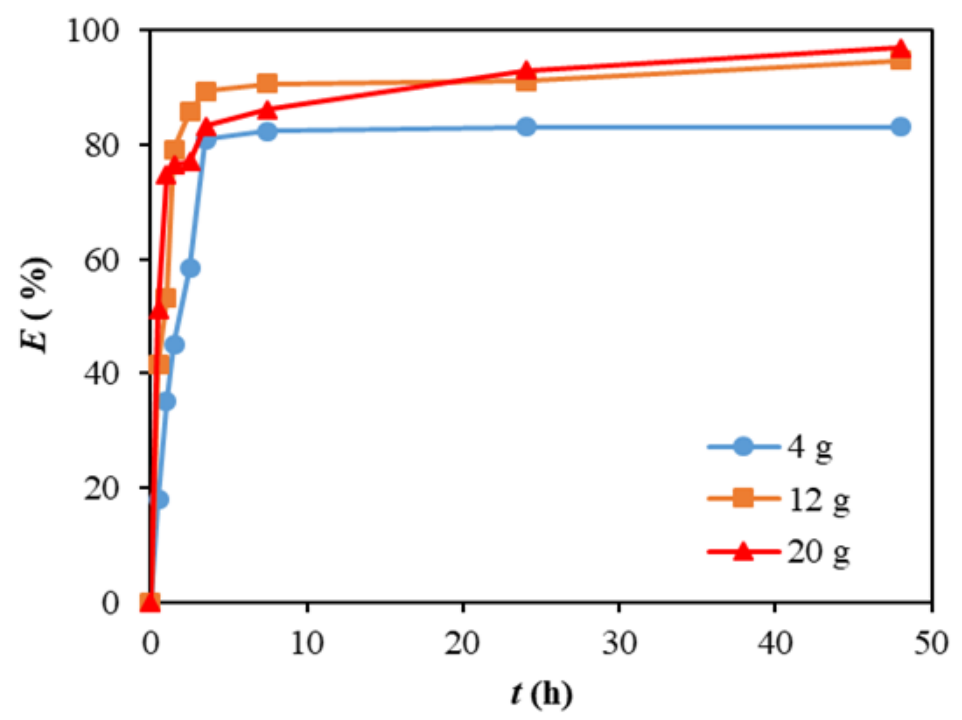

Figure 4. The efficiency of $\mathrm{PO}_{4}{ }^{3-}$ removal from synthetic solution.

The relationship of $E$ against $m$ and $q$ against $m$ for the adsorption of $\mathrm{PO}_{4}{ }^{3-}$ onto ICWMS is depicted in Figure 5. $E$ gradually increases from 86.1 to $96.9 \%$; however, $q$ gradually decreases from 0.30 to $0.07 \mathrm{mg} \mathrm{g}^{-1}$ when $m$ increasing from 4 to $20 \mathrm{~g}$ as illustrated in Figure 5 . More adsorbents used in a batch experiment could have more active sites available to adsorb $\mathrm{PO}_{4}{ }^{3-}$ from a synthetic solution. Thus, the $E$ increases [45]. The $q$ decreases as $m$ increases because at high ICWMS adsorbent dosages, the available number of $\mathrm{PO}_{4}{ }^{3-}$ solute in aqueous solution is insufficient to completely bind with all available surface binding sites on the ICWMS adsorbent [46].

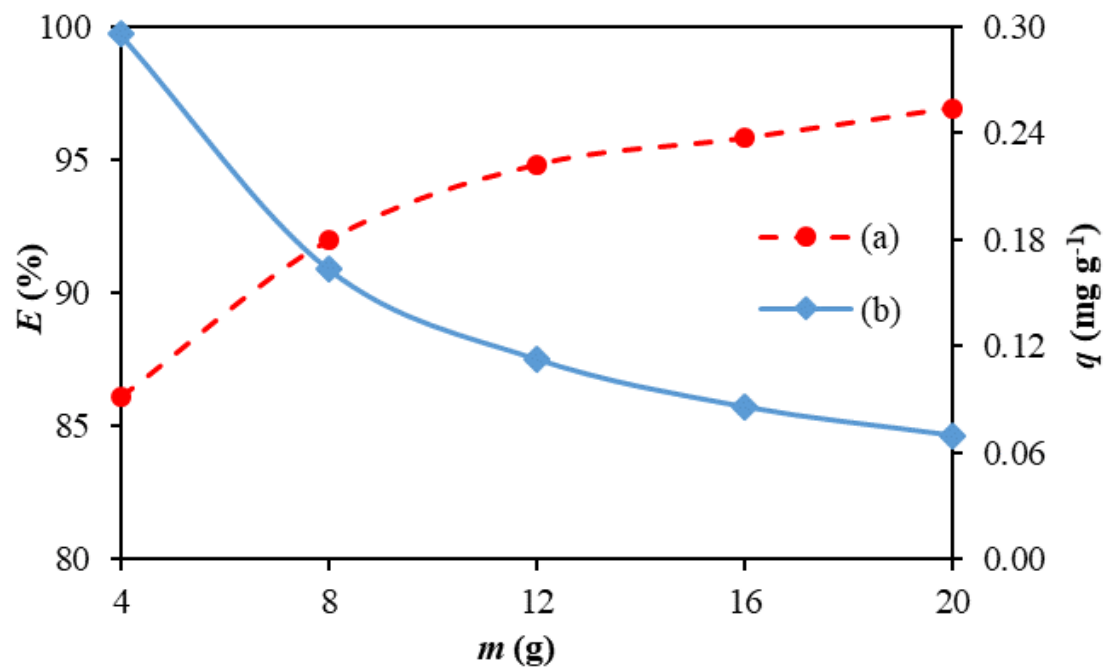

Figure 5. Relationship of: (a) $E$ against $m$ and (b) $q$ against $m$ for the adsorption of $\mathrm{PO}_{4}{ }^{3-}$ onto ICWMS. 


\subsection{Adsorption kinetics of $\mathrm{PO}_{4}{ }^{3-}$ onto the ICWMS.}

The value of $F_{\mathrm{e}}$ can be calculated according to the following equation [47]. The most appropriate model, either PFO or PSO should have the highest $R^{2}$ and smallest $F_{\mathrm{e}}$ value.

$$
F_{e}=\sqrt{\left(\frac{1}{\bullet n-p}\right) \sum_{i}^{n}\left(q_{t(\exp )}-q_{t(\text { theo })}\right)^{2}}
$$

where $n$ is the number of measurements, $p$ is the number of kinetic parameters, $q_{t(\exp )}$ is the experimental $q$ value, and $q_{t \text { (theo) }}$ is the theoretical $q$ value $\left(\mathrm{mg} \mathrm{g}^{-1}\right)$.

The kinetic parameters obtained from the PFO and PSO models are shown in Table 4. The $\left(R^{2}=0.999\right)$ for PSO model was higher than that $\left(R^{2}>0.698\right)$ for PFO model, as shown in Table 4. This study verifies that the PSO model could be more suitable than PFO model due to the lower value of $F_{e}$ and the higher value of $R^{2}$ have been evaluated (Table 4). According to the results of this study, the adsorption of $\mathrm{PO}_{4}{ }^{3-}$ onto ICWMS can be categorized as chemical adsorption; $\mathrm{H}_{2} \mathrm{PO}_{4}{ }^{-}$and $\mathrm{HPO}_{4}{ }^{2-}$ react with some oxides present on the surface of ICWMS (i.e., $\mathrm{Ca}-\mathrm{O}-\mathrm{H}$ and $\mathrm{Fe}-\mathrm{O}-\mathrm{H})$ via hydrogen bonding [48]. The value of $k_{2}$ increases from 0.052 to 0.297 and to $0.392 \mathrm{~g} \mathrm{mg}^{-1} \mathrm{~min}^{-1}$ with an increasing amount of the ICWMS from 4 to 12 and to $20 \mathrm{~g}$, meaning that the rate of $\mathrm{PO}_{4}{ }^{3-}$ adsorption onto ICWMS can be increased by increasing the amount of ICWMS [49,50].

Table 4. The kinetic parameters were obtained from the PFO and PSO models.

\begin{tabular}{|c|c|c|c|c|c|c|}
\hline \multirow{2}{*}{ Sample } & \multirow{2}{*}{$\frac{\text { Amount }}{(\mathrm{g})}$} & \multicolumn{3}{|c|}{ PFO model } & \multirow[b]{2}{*}{$F_{\mathrm{e}}$} & \multirow[b]{2}{*}{$q_{\mathrm{e}}(\exp )$} \\
\hline & & $q_{\mathrm{e}}$ (theo) & $k_{1}$ & $R^{2}$ & & \\
\hline & & $\left(\mathrm{mg} \mathrm{g}^{-1}\right)$ & $\left(\mathrm{min}^{-1}\right)$ & & & $\left(\mathrm{mg} \mathrm{g}^{-1}\right)$ \\
\hline \multirow[t]{4}{*}{ Synthetic solution } & 4 & 0.30 & 0.012 & 0.881 & 0.033 & 0.30 \\
\hline & 12 & 0.04 & 0.006 & 0.721 & 0.081 & 0.11 \\
\hline & 20 & 0.02 & 0.003 & 0.698 & 0.057 & 0.07 \\
\hline & Amount & \multicolumn{3}{|c|}{ PSO model } & & \\
\hline \multirow[t]{2}{*}{ Sample } & $(\mathrm{g})$ & $q_{\mathrm{e}}($ theo $)$ & $k_{2}$ & $R^{2}$ & $F_{\mathrm{e}}$ & $q_{\mathrm{e}}(\exp )$ \\
\hline & & $\left(\mathrm{mg} \mathrm{g}^{-1}\right)$ & $\left(\mathrm{g} \mathrm{mg}^{-1} \mathrm{~min}^{-1}\right)$ & & & $\left(\mathrm{mg} \mathrm{g}^{-1}\right)$ \\
\hline \multirow[t]{3}{*}{ Synthetic solution } & 4 & 0.30 & 0.052 & 0.999 & 0.031 & 0.30 \\
\hline & 12 & 0.11 & 0.297 & 0.999 & 0.152 & 0.11 \\
\hline & 20 & 0.07 & 0.392 & 0.999 & 0.005 & 0.07 \\
\hline
\end{tabular}

\subsection{Adsorption isotherms of $\mathrm{PO}_{4}^{3-}$ onto the ICWMS.}

The experimental data were analyzed using the linearized forms of the Freundlich and Langmuir isotherm models. The results (see Table 5) represent the parameters obtained from the Freundlich and Langmuir models. This study suggested that the experimental data agreed with the Freundlich model $\left(R^{2}=0.996\right.$; see Table 5$)$. The adsorption of $\mathrm{PO}_{4}{ }^{3-}$ occurred on the heterogeneous site of ICWMS progression with multilayer adsorption, meaning that the adsorbed $\mathrm{PO}_{4}{ }^{3-}$ on the surface of ICWMS can capture more $\mathrm{PO}_{4}{ }^{3-}$ from bulk water. The surfaces of the ICWMS are heterogeneous, and sorption of $\mathrm{PO}_{4}{ }^{3-}$ onto ICWMS occurs in the form of multilayers [51,52]. The $n$ value of 1.16 was verified (see Table 5). It indicates favorable adsorption, active sites with the highest binding energies would be used first for less heterogeneous surfaces and then pursued by weaker sites for more heterogeneous surfaces $[53,54]$.

Table 5. The adsorption isotherm parameters.

\begin{tabular}{l|c|c|c|c|c|c} 
& \multicolumn{3}{|c|}{ Freundlich model } & \multicolumn{3}{c}{ Langmuir model } \\
\hline Sample & $n$ & $K_{\mathrm{F}}$ & $R^{2}$ & $q_{\max }$ & $K_{\mathrm{L}}$ & $R^{2}$ \\
\hline Synthetic solution & 1.16 & $\left(\mathrm{mg} \mathrm{g}^{-1}\right)$ & & $\left(\mathrm{mg} \mathrm{g}^{-1}\right)$ & $\left(\mathrm{L} \mathrm{mg}^{-1}\right)$ & \\
\hline
\end{tabular}




\subsection{Comparison of the adsorption capacities.}

The comparison of the $\mathrm{PO}_{4}{ }^{3-}$ adsorption capacities for $\mathrm{PO}_{4}{ }^{3-}$ adsorption onto various adsorbents, as had been done by previous researchers, is shown in Table 6 . The adsorption capacity of coarse mussel shell and mussel shell with their particle sizes of less than $3.0 \mathrm{~mm}$ as high as $1.00 \mathrm{mg} \mathrm{g}^{-1}$ and $0.10 \mathrm{mg} \mathrm{g-1,} \mathrm{respectively,} \mathrm{has} \mathrm{been} \mathrm{verified} \mathrm{[7].} \mathrm{The} \mathrm{use} \mathrm{of} \mathrm{ICWMS}$ with its adsorption capacity of $0.30 \mathrm{mg} \mathrm{g}^{-1}$ is better than that of raw mussel shell with its adsorption capacity of $0.05 \mathrm{mg} \mathrm{g}^{-1}$ for removing PO43 from aqueous solution [16]. Another study by Chen et al. [55] reported that the adsorption capacity of $0.119 \mathrm{mg} \mathrm{g}^{-1}$ was obtained to remove PO43 from wastewater by an oyster shell.

Table 6. Comparison of the $\mathrm{PO}_{4}{ }^{3-}$ adsorption capacities of the various adsorbent.

\begin{tabular}{l|c|c|c|c|c|c|c} 
Adsorbent & $\begin{array}{c}\boldsymbol{C}_{\boldsymbol{i}} \\
\left(\mathbf{m g ~ L}^{-\mathbf{1}}\right)\end{array}$ & $\begin{array}{c}\text { Dosage } \\
\left(\mathbf{g ~ L}^{-\mathbf{1}}\right)\end{array}$ & $\begin{array}{c}\text { Duration } \\
(\mathbf{h})\end{array}$ & $\begin{array}{c}\mathbf{q}_{\mathbf{e}(\mathbf{e x p})} \\
\left(\mathbf{m g ~ g}^{-\mathbf{1}}\right)\end{array}$ & $\begin{array}{c}\text { Size of particles } \\
(\mathbf{m m})\end{array}$ & $\mathbf{p H}$ & References \\
\hline Mussel shell & 5 & 2 & 50 & 0.10 & 0.60 to 1.18 & 7 & {$[7]$} \\
\hline Mussel shell & 15 & 13 & 72 & 0.05 & 1.5 & 9.2 & {$[16]$} \\
\hline Coarse Mussel shell & 0.5 & 100 & $\mathrm{n} / \mathrm{a}$ & 1.00 & 0.5 to 3.0 & 9.1 & {$[56]$} \\
\hline Fine Mussel Shell & 0.5 & 100 & $\mathrm{n} / \mathrm{a}$ & $<0.43$ & $<1$ & 9.3 & {$[56]$} \\
\hline Oyster Shell & 3 & 25 & 48 & 0.119 & $<200$ & 7 & {$[56]$} \\
\hline Zeolite Clinoptilolite & 3 & 0.075 & 24 & 0 & n/a & 5.9 & {$[57]$} \\
\hline Hardwood & 24 & 5 & 24 & 0.24 & $<2$ & 8.5 & {$[58]$} \\
\hline Shale & 25 & 80 & 24 & 0.23 & 1 to 2 & 11 & {$[59]$} \\
\hline ICWMS & 7 & 20 & 48 & 0.30 & 0.60 to 1.18 & 7 & This study
\end{tabular}

Remarks that $\mathrm{n} / \mathrm{a}$ is not available.

\section{Conclusions}

The feasibility of using ICWMS as an adsorbent for the removal of $\mathrm{PO}_{4}{ }^{3-}$ in an aqueous solution was explored. The adsorption kinetic data agreed with the PSO model $\left(R^{2}=0.999\right)$, suggesting that the adsorption phenomena between ICWMS and $\mathrm{PO}_{4}{ }^{3-}$ could be leading to chemisorption. The adsorption isotherm data were well fitted to the Freundlich model $\left(R^{2}=\right.$ 0.996), implying that the adsorption of $\mathrm{PO}_{4}{ }^{3-}$ onto ICWMS from synthetic solution would occur as a multilayer. The results findings can help solve the excessive amounts of PO43problem using ICWMS as an adsorbent and thus potentially improve environmental quality.

\section{Funding}

This research was supported by the Ministry of Education (MOE) through Fundamental Research Grant Scheme (FRGS/1/2017/TK10/UTM/02/9). We also want to thank the Government of Malaysia, which provides the MyBrain 15 program for sponsoring this work under the self-funded research grant and L00022 from the Ministry of Science, Technology and Innovation (MOSTI).

\section{Acknowledgments}

We thank the Centre for Environmental Sustainability and Water Security (IPASA) for laboratory facilities and Indah Water Konsortium (IWK) Sdn. Bhd. for research collaboration.

\section{Conflicts of Interest}

The authors declare no conflict of interest. 


\section{References}

1. Wu, K.; Li, Y.; Liu, T.; Huang, Q.; Yang, S.; Wang, W.; Jin, P. The simultaneous adsorption of nitrate and phosphate by an organic-modified aluminum-manganese bimetal oxide: Adsorption properties and mechanisms. Applied Surface Science 2019, 478, 539-551, https://doi.org/10.1016/j.apsusc.2019.01.194.

2. Salim, N.A.A.; Puteh, M.H.; Yusoff, A.R.M.; Abdullah, N.H., Fulazzaky, M.A.; Rudie Arman, M.A.Z.; Zainuddin, N.A. Adsorption isotherms and kinetics of phosphate on waste mussel shell. Malaysian Journal of Fundamental and Apllied Sciences 2020, 16, 393-399, https://doi.org/10.11113/mjfas.v16n3.1752.

3. Salim, N.A.A.; Abdullah, N.H.; Ahmad, N.; Puteh, M.H. Issues and technology in water contaminants 2020, 121-138. UTM Press, Malaysia.Li, R.; Wang, J.J.; Zhou, B.; Awasthi, M.K.; Ali, A.; Zhang, Z.; Mahar, A. Enhancing phosphate adsorption by $\mathrm{Mg} / \mathrm{Al}$ layered double hydroxide functionalized biochar with different $\mathrm{Mg} / \mathrm{Al}$ ratios. Science of the Total Environment 2016, 559, 121-129.

4. Li, R.; Wang, J.J.; Zhou, B; Enhancing phosphate adsorption by Mg/Al layered double hydroxide functionalized biochar with different Mg/Al ratios. Science Total Environment 2016, 559, 121-129, https://doi.org/10.1016/j.scitotenv.2016.03.151.

5. Caravelli, A.H.; Contreras, E.M.; Zaritzky, N.E. Phosphorous removal in batch systems using ferric chloride in the presence of activated sludges. Journal of Hazardous Materials 2010, 177, 199-208, https://doi.org/10.1016/j.jhazmat.2009.12.018.

6. Fulazzaky, M.A.; Salim, N.A.A.; Abdullah, N.H.; Mohd Yusoff, A.R.; Paul, E. Precipitation of ironhydroxy-phosphate of added ferric iron from domestic wastewater by an alternating aerobic-anoxic process. Chemical Engineering Journal 2014, 253, 291-297, https://doi.org/10.1016/j.cej.2014.05.049.

7. Salim, N.A.A; Abdullah, N.H.; Khairuddin, M.R.; Rudie Arman, M.A.Z.; Khamidun, M.H.; Fulazzaky, M.A.; Puteh, M.H. Adsorption of phosphate from aqueous solutions using waste mussel shell. MATEC Web of Conferences 2018, 250, https://doi.org/10.1051/matecconf/201825006013.

8. Oladoja, N.A.; Ahmad, A.L.; Adesina, O.A.; Adelagun, R.O.A. Low-cost biogenic waste for phosphate capture from aqueous system. Chemical Engineering Journal 2012, 209, 170-179, https://doi.org/10.1016/j.cej.2012.07.125.

9. Nagoya, S.; Nakamichi, S.; Kawase, Y. Mechanisms of phosphate removal from aqueous solution by zerovalent iron: A novel kinetic model for electrostatic adsorption, surface complexation and precipitation of phosphate under oxic conditions. Separation and Purification Technology 2019, 218, 120-129, https://doi.org/10.1016/j.seppur.2019.02.042.

10. Lalley, J.; Han, C.; Li, X.; Dionysiou, D.D.; Nadagouda, M.N. Phosphate adsorption using modified iron oxide-based sorbents in lake water: Kinetics, equilibrium, and column tests. Chemical Engineering Journal 2016, 284, 1386-1396, https://doi.org/10.1016/j.cej.2015.08.114.

11. Gupta, V.K.; Sadegh, H.; Yari, M.; Shahryari Ghoshekandi, R.; Maazinejad, B.; Chahardori, M. Removal of ammonium ions from wastewater A short review in development of efficient methods. Global Journal of Environmental Science and Management 2015, 1, 149-158, https://doi.org/10.7508/gjesm.2015.02.007.

12. Worch, E. Adsorption Technology in Water Treatment: Fundamentals, Processes, and Modeling. Germany: Walter de Gruyter GmbH \& Co. KG, Boston. 2012; https://doi.org/10.1515/9783110240238.

13. Lü, J.; Sun, L.; Zhao, X.; Lu, B.; Li, Y.; Zhang, L. Removal of phosphate from aqueous solution using ironoxide-coated sand filter media: Batch studies. Proceedings -International Conference on Environmental Science and Information Application Technology, ESIAT 2009, 1, 639-644, https://doi.org/10.1109/ESIAT.2009.104.

14. Boujelben, N.; Bouzid, J.; Elouear, Z.; Feki, M.; Jamoussi, F.; Montiel, A. Phosphorus removal from aqueous solution using iron coated natural and engineered sorbents. Journal of Hazardous Materials 2008, 151, 103110, https://doi.org/10.1016/j.jhazmat.2007.05.057.

15. Mezenner, N.Y.; Bensmaili, A. Kinetics and thermodynamic study of phosphate adsorption on iron hydroxide-eggshell waste. Chemical Engineering Journal 2009, 147, 87-96, https://doi.org/10.1016/j.cej.2008.06.024.

16. Paradelo, R.; Conde-Cid, M.; Cutillas-Barreiro, L.; Arias-Estévez, M.; Nóvoa-Muñoz, J. C.C.; ÁlvarezRodríguez, E.; Núñez-Delgado, A. Phosphorus removal from wastewater using mussel shell: Investigation on retention mechanisms. Ecological Engineering 2016, 97, 558-566, https://doi.org/10.1016/j.ecoleng.2016.10.066.

17. Azizian, S. Kinetic models of sorption: A theoretical analysis. Journal of Colloid and Interface Science 2004 , 276, 47-52, https://doi.org/10.1016/j.jcis.2004.03.048.

18. Liu, Y.; Shen, L. From Langmuir kinetics to first- and second-order rate equations for adsorption. Langmuir 2008, 24, 11625-11630, https://doi.org/10.1021/la801839b.

19. Ho, Y.S.; McKay, G. A Comparison of chemisorption kinetic models applied to pollutant removal on various sorbents. Process Safety and Environmental Protection 1998, 76, 332-340, https://doi.org/10.1205/095758298529696.

20. Qiu, H.; Lv, L.; Pan, B.; Zhang, Q.; Zhang, W.; Zhang, Q. Critical review in adsorption kinetic models. Journal of Zhejiang University-SCIENCE A 2009, 10, 716-724, https://doi.org/10.1631/jzus.A0820524. 
21. Hubadillah, S.K.; Othman, M.H.D.; Harun, Z.; Ismail, A.F.; Rahman, M.A.; Jaafar, J. A Novel green ceramic hollow fiber membrane (CHFM) derived from rice husk ash as combined adsorbent-separator for efficient heavy metals removal. Ceramics International 2017, 43, 4716-4720, https://doi.org/10.1016/j.ceramint.2016.12.122.

22. Ho, Y.S. Review of second-order models for adsorption systems. Journal of Hazardous Materials 2006, 136, 681-689, https://doi.org/10.1016/j.jhazmat.2005.12.043.

23. Rashidi Nodeh, H.; Sereshti, H.; Zamiri Afsharian, E.; Nouri, N. Enhanced removal of phosphate and nitrate ions from aqueous media using nanosized lanthanum hydrous doped on magnetic graphene nanocomposite. Journal of Environmental Management $2017, \quad$ 2017, https://doi.org/10.1016/j.jenvman.2017.04.004.

24. Singh, N.B.; Nagpal, G.; Agrawal, S.; Rachna. Water purification by using adsorbents: A Review. Environmental Technology and Innovation 2018, 11, 187-240, https://doi.org/10.1016/j.eti.2018.05.006.

25. Efome, J.E.; Rana, D.; Matsuura, T.; Lan, C.Q. Metal-organic frameworks supported on nanofibers to remove heavy metals. Journal of Materials Chemistry A 2018, 6, 4550-4555, https://doi.org/10.1039/C7TA10428F.

26. Li, R.; Kelly, C.; Keegan, R.; Xiao, L.; Morrison, L.; Zhan, X. Phosphorus removal from wastewater using natural pyrrhotite. Colloids and Surfaces A: Physicochemical and Engineering Aspects 2013, 427, 13-18, https://doi.org/10.1016/j.colsurfa.2013.02.066.

27. Lai, C.; Yeh, S.; Chen, M.; Wang, M.; Huang, L. Lead removal in iron-coated medium in the presence of humic acid : pH effect. Sustainable Environment Research 2010, 20, 361-367.

28. American Public Health Association (APHA). Standard Methods for the Examination of Water and Wastewater. 21st ed., Springer, Washington DC, 2005.

29. Torit, J.; Phihusut, D. Phosphorus removal from wastewater using eggshell ash. Environmental Science and Pollution Research 2019, 26, 34101-34109, https://doi.org/10.1007/s11356-018-3305-3.

30. Nam, G.; Choi, Y.-H.H.; Lee, N.; Ahn, J.W. Effect by alkaline flocculation of algae and phosphorous from water using a calcined waste oyster shell. Water (Switzerland) 2017, 9, https://doi.org/10.3390/w9090661.

31. Nurdin, S.; Rosnan, N.A.; Ghazali, N.S.; Gimbun, J.; Nour, A.H.; Haron, S.F. Economical Biodiesel Fuel Synthesis from Castor Oil Using Mussel Shell-Base Catalyst (MS-BC). Energy Procedia 2015. 79, 576-583, https://doi.org/10.1016/j.egypro.2015.11.536.

32. Arulvel, S.; Elayaperumal, A.; Jagatheeshwaran, M.S. Electroless nickel - phosphorus coating on crab shell particles and its characterization. Journal of Solid State Chemistry 2017, 248, 87-95, https://doi.org/10.1016/j.jssc.2017.02.001.

33. Fu, H.; Yang, Y.; Zhu, R.; Liu, J.; Usman, M.; Chen, Q.; He, H. Superior adsorption of phosphate by ferrihydrite-coated and lanthanum-decorated magnetite. Journal of Colloid and Interface Science 2018, 530, 704-713, https://doi.org/10.1016/j.jcis.2018.07.025.

34. Mitrogiannis, D.; Psychoyou, M.; Baziotis, I.; Inglezakis, V.J.; Koukouzas, N.; Tsoukalas, N.; Markou, G. Removal of phosphate from aqueous solutions by adsorption onto $\mathrm{Ca}(\mathrm{OH})_{2}$ treated natural clinoptilolite. Chemical Engineering Journal 2017, 320, 510-522, https://doi.org/10.1016/j.cej.2017.03.063.

35. Mazzetti, L.; Thistlethwaite, P.J. Raman spectra and thermal transformations of ferrihydrite and schwertmannite. Journal of Raman Spectroscopy 2002, 33, 104-111.

36. Yan, J.; Jiang, T.; Yao, Y.; Lu, S.; Wang, Q.; Wei, S. Preliminary investigation of phosphorus adsorption onto two types of iron oxide-organic matter complexes. Journal of Environmental Sciences (China) 2016, 42, 152-162, https://doi.org/10.1016/j.jes.2015.08.008.

37. Pap, S.; Kirk, C.; Bremner, B.; Turk Sekulic, M.; Gibb, S.W.; Maletic, S.; Taggart, M.A. Synthesis optimisation and characterisation of chitosan-calcite adsorbent from fishery-food waste for phosphorus removal. Environmental Science and Pollution Research 2020, 27, 9790-9802, https://doi.org/10.1007/s11356-019-07570-0.

38. Cao, D.; Jin, X.; Gan, L.; Wang, T.; Chen, Z. Removal of phosphate using iron oxide nanoparticles synthesized by eucalyptus leaf extract in the presence of CTAB surfactant. Chemosphere 2016, 159, 23-31, https://doi.org/10.1016/j.chemosphere.2016.05.080.

39. Han, J.K.; Song, H.Y.; Saito, F.; Lee, B.T. Synthesis of high purity nano-sized hydroxyapatite powder by microwave-hydrothermal method. Materials Chemistry and Physics 2006, 99, 235-239, https://doi.org/10.1016/j.matchemphys.2005.10.017.

40. Theophile, T.; Berzina-Cimdina, L.; Borodajenko, N. Research of Calcium Phosphates Using Fourier Transform Infrared Spectroscopy. InTech Published, Croatia, 2012; pp. 576-583, https://doi.org/10.5772/36942.

41. Ashrit, S.S.; Chatti, R.V.; Sarkar, S. Synthesis and characterization of hematite-based calcium rich hydroxyapatite-A nano material from LD slag fines. Journal of Environmental Chemical Engineering 2020, 8, https://doi.org/10.1016/j.jece.2019.103581.

42. Wu, S.-C.C.; Hsu H.-C.C.; Hsu, S.-K.K.; Tseng C.-P.P.; Ho, W.-F.F. Preparation and characterization of hydroxyapatite synthesized from oyster shell powders. Advances Powder Technology 2017, 28, 1154-1158, https://doi.org/10.1016/j.apt.2017.02.001. 
43. Li, M.; Liu, J.; Xu, Y.; Qian, G.; Li, M.; Xu, Y. Phosphate adsorption on metal oxides and metal hydroxides: A comparative review. Environmental Reviews 2016, 332, 1-58, https://doi.org/10.1139/er-2015-0080.

44. Zhang, L.; Gao, Y.; Xu, Y.; Liu, J. Different performances and mechanisms of phosphate adsorption onto metal oxides and metal hydroxides: A comparative study. Journal of Chemical Technology and Biotechnology 2016, 91, 1232-1239.

45. Bagali, S.S.; Gowrishankar, B.S.; Roy, A.S. Optimization, kinetics, and equilibrium studies on the removal of lead(ii) from an aqueous solution using banana pseudostem as an adsorbent. Engineering 2017, 3, 409415, https://doi.org/10.1016/J.ENG.2017.03.024.

46. Zhai, L.; Bai, Z.; Zhu, Y.; Wang, B.; Luo, W. Fabrication of chitosan microspheres for efficient adsorption of methyl orange. Chinese Journal of Chemical Engineering 2018, 26, 657-666, https://doi.org/10.1016/j.cjche.2017.08.015.

47. Ribas, M.C.; Adebayo, M.A.; Prola, L D T.; Lima, E.C.; Cataluña, R.; Feris, L.A.; Calvete, T. Comparison of a homemade cocoa shell activated carbon with commercial activated carbon for the removal of reactive violet 5 dye from aqueous solutions. Chemical Engineering Journal 2014, 248, 315-326, https://doi.org/10.1016/j.cej.2014.03.054.

48. Dos Reis, G.S.; Grigore Cazacliu, B.; Rodriguez Correa, C.; Ovsyannikova, E.; Kruse, A.; Hoffmann Sampaio, C.; Lima, E.C.; Dotto, G.L. Adsorption and recovery of phosphate from aqueous solution by the construction and demolition wastes sludge and its potential use as phosphate-based fertiliser. Journal of Environmental Chemical Engineering 2020, 8, https://doi.org/10.1016/j.jece.2019.103605.

49. Song, X.; Pan, Y.; Wu, Q.; Cheng, Z.; Ma, W. Phosphate removal from aqueous solutions by adsorption using ferric sludge. Desalination 2011, 280, 384-390, https://doi.org/10.1016/j.desal.2011.07.028.

50. Salim, N.A.A.; Puteh, M.H.; Abdullah, N.H.; Khamidun, M.H.; Fulazzaky, M.A.; Yusoff, A.R.M.; Zaini, M.A.A. Kinetics study of phosphate adsorption onto waste mussel shell. International Conference on Environmental Sustainability and Resource Security (IC-ENSURES) 2019, 1, 201-205.

51. Almasri, D.A.; Saleh, N.B.; Atieh, M.A.; McKay, G.; Ahzi, S. Adsorption of phosphate on iron oxide doped halloysite nanotubes. Scientific Reports 2019, 9, https://doi.org/10.1038/S41598-019-39035-2.

52. Arshadi, M.; Mousavinia, F.; Amiri, M.J.; Faraji, A.R. Adsorption of methyl orange and salicylic acid on a nano-transition metal composite: Kinetics, thermodynamic and electrochemical studies. Journal of Colloid and Interface Science 2016, 483, 118-131, https://doi.org/10.1016/j.jcis.2016.08.032.

53. Marañón, E.; Ulmanu, M.; Fernández, Y.; Anger, I.; Castrillón, L. Removal of ammonium from aqueous solutions with volcanic tuff. Journal of Hazardous Materials 2006, 137, 1402-1409, https://doi.org/10.1016/j.jhazmat.2006.03.069.

54. Kaya, E.M.Ö.; Özcan, A.S.; Gök, Ö.; Özcan, A. Adsorption kinetics and isotherm parameters of naphthalene onto natural- and chemically modified bentonite from aqueous solutions. Adsorption 2013, 19, 879-888, https://doi.org/10.1007/s10450-013-9542-3.

55. Chen, J.; Cai, Y.; Clark, M.; Yu, Y. Equilibrium and Kinetic Studies of Phosphate Removal from Solution onto a Hydrothermally Modified Oyster Shell Material. PLoS ONE 2013, 8, 1-10, https://doi.org/10.1371/journal.pone.0060243.

56. Romar-Gasalla, A.; Rivas-Pérez, I.M.; Paradelo-Núñez, R.; Nóvoa-Muñoz, J.C.; Arias-Estévez, M.; Fernández-Sanjurjo, M.J.; Núñez-Delgado, A. Phosphorus retention on forest and vineyard soil samples, mussel shell, pine-sawdust, and on pyritic, granitic and waste materials. Geoderma 2016, 280, 8-13, https://doi.org/10.1016/j.geoderma.2016.06.003.

57. Ooi, K.; Sonoda, A.; Makita, Y.; Torimura, M. Comparative study on phosphate adsorption by inorganic and organic adsorbents from a diluted solution. Journal of Environmental Chemical Engineering 2017, 5, 31813189, https://doi.org/10.1016/j.jece.2017.06.015.

58. Yin, Q.; Zhang, B.; Wang, R.; Zhao, Z. Biochar as an adsorbent for inorganic nitrogen and phosphorus removal from water: a review. Environmental Science and Pollution Research 2017, 24, 26297-26309, https://doi.org/10.1007/s11356-017-0338-y.

59. Kpannieu, D.E.; Mallet, M.; Coulibaly, L.; Abdelmoula, M.; Ruby, C. Phosphate removal from water by naturally occurring shale, sandstone, and laterite: The role of iron oxides and of soluble species. Comptes Rendus - Geoscience 2019, 351, 37-47, https://doi.org/10.1016/j.crte.2018.09.004. 